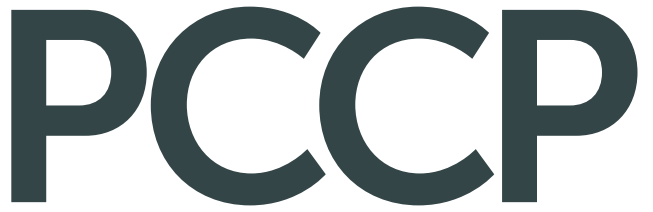

Physical Chemistry Chemical Physics www.rsc.org/pccp
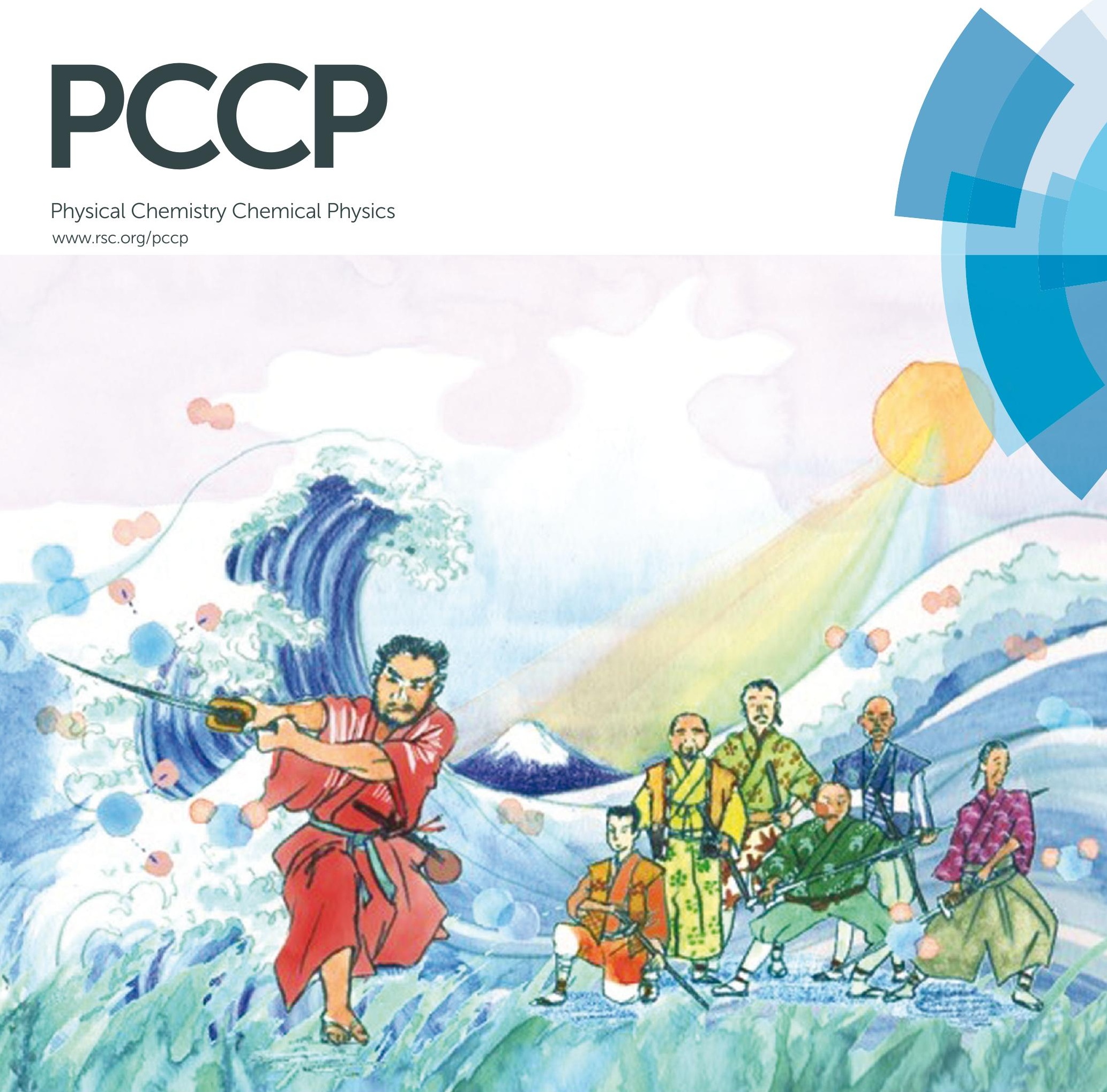

ISSN 1463-9076

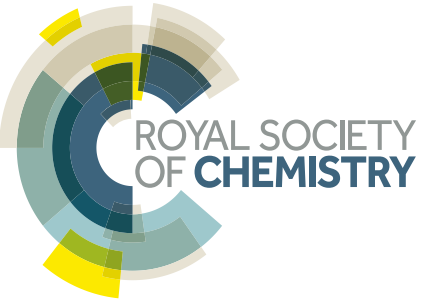

\section{PAPER}

Hiroshi Irie et al.

A heterojunction photocatalyst composed of zinc rhodium oxide, single crystal-derived bismuth vanadium oxide, and silver for overall pure-water splitting under visible light up to $740 \mathrm{~nm}$ 


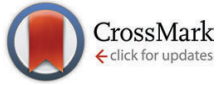

Cite this: Phys. Chem. Chem. Phys., 2016, 18, 27754

Received 30th April 2016, Accepted 30th June 2016 DOI: 10.1039/c6cp02903e

www.rsc.org/pccp

\title{
A heterojunction photocatalyst composed of zinc rhodium oxide, single crystal-derived bismuth vanadium oxide, and silver for overall pure-water splitting under visible light up to $\mathbf{7 4 0} \mathbf{n m} \dagger$
}

\author{
Ryoya Kobayashi, ${ }^{a}$ Toshihiro Takashima, ${ }^{\text {b }}$ Satoshi Tanigawa, ${ }^{\text {a Shugo Takeuchi, }}{ }^{c}$ \\ Bunsho Ohtani ${ }^{d}$ and Hiroshi Irie ${ }^{* b d}$
}

\begin{abstract}
We recently reported the synthesis of a solid-state heterojunction photocatalyst consisting of zinc rhodium oxide $\left(\mathrm{ZnRh}_{2} \mathrm{O}_{4}\right)$ and bismuth vanadium oxide $\left(\mathrm{Bi}_{4} \mathrm{~V}_{2} \mathrm{O}_{11}\right)$, which functioned as hydrogen $\left(\mathrm{H}_{2}\right)$ and oxygen $\left(\mathrm{O}_{2}\right)$ evolution photocatalysts, respectively, connected with silver (Ag). Polycrystalline $\mathrm{Bi}_{4} \mathrm{~V}_{2} \mathrm{O}_{11}\left(p-\mathrm{Bi}_{4} \mathrm{~V}_{2} \mathrm{O}_{11}\right)$ powders were utilized to form $\mathrm{ZnRh}_{2} \mathrm{O}_{4} / \mathrm{Ag} / \mathrm{p}-\mathrm{Bi}_{4} \mathrm{~V}_{2} \mathrm{O}_{11}$, which was able to photocatalyze overall pure-water splitting under red-light irradiation with a wavelength of $700 \mathrm{~nm}$ (R. Kobayashi et al., J. Mater. Chem. A, 2016, 4, 3061). In the present study, we replaced $\mathrm{p}-\mathrm{Bi}_{4} \mathrm{~V}_{2} \mathrm{O}_{11}$ with a powder obtained by pulverizing single crystals of $\mathrm{Bi}_{4} \mathrm{~V}_{2} \mathrm{O}_{11}\left(\mathrm{~s}-\mathrm{Bi}_{4} \mathrm{~V}_{2} \mathrm{O}_{11}\right.$ ) to form $\mathrm{ZnRh} 2 \mathrm{O}_{4} / \mathrm{Ag} / \mathrm{s}-\mathrm{Bi}_{4} \mathrm{~V}_{2} \mathrm{O}_{11}$, and demonstrated that this heterojunction photocatalyst had enhanced water-splitting activity. In addition, $\mathrm{ZnRh}_{2} \mathrm{O}_{4} / \mathrm{Ag} / \mathrm{s}-\mathrm{Bi}_{4} \mathrm{~V}_{2} \mathrm{O}_{11}$ was able to utilize nearly the entire range of visible light up to a wavelength of $740 \mathrm{~nm}$. These properties were attributable to the higher $\mathrm{O}_{2}$ evolution activity of $\mathrm{s}-\mathrm{Bi}_{4} \mathrm{~V}_{2} \mathrm{O}_{11}$
\end{abstract}

\section{Introduction}

Since the first report of photo-induced water splitting by titanium dioxide $\left(\mathrm{TiO}_{2}\right)$ and platinum (Pt) electrodes, ${ }^{1}$ the potential to convert photon energy into hydrogen $\left(\mathrm{H}_{2}\right)$ energy by photocatalytic water-splitting using photoelectrodes and powdered photocatalysts has been extensively investigated due to the simplicity of the process and the possibility for large-scale $\mathrm{H}_{2}$ production. Numerous studies have attempted to identify powdered photocatalysts that are able to split water into $\mathrm{H}_{2}$ and oxygen $\left(\mathrm{O}_{2}\right)$ at a molar ratio of $\sim 2: 1$ (overall water splitting), ${ }^{2-26}$ particularly under visible-light irradiation for the efficient utilization of sunlight energy. ${ }^{8-26}$ One of the major approaches for overall water splitting is the construction of "Z-scheme" systems, which are composed of two visible-light sensitive photocatalysts. These systems were first reported by Sayama and coworkers, who used Pt-deposited strontium titanate co-doped

\footnotetext{
${ }^{a}$ Special Doctoral Program for Green Energy Conversion Science and Technology, Interdisciplinary Graduate School of Medicine and Engineering, University of Yamanashi, 4-3-11 Takeda, Kofu, Yamanashi 400-8511, Japan

${ }^{b}$ Clean Energy Research Center, University of Yamanashi, 4-3-11 Takeda, Kofu, Yamanashi 400-8511, Japan. E-mail: hirie@yamanashi.ac.jp

${ }^{c}$ Graduate School of Environmental Science, Hokkaido University, Nishi 10, Nishi 5, Sapporo, Hokkaido 060-0810, Japan

${ }^{d}$ Institute for Catalysis, Hokkaido University, Nishi 10, Kita 21, Sapporo, Hokkaido 001-0021, Japan

$\dagger$ Electronic supplementary information (ESI) available. See DOI: 10.1039/c6cp02903e
}

with chromium and tantalum $\left(\mathrm{Pt} / \mathrm{SrTiO}_{3}: \mathrm{Cr}, \mathrm{Ta}\right)$ as an $\mathrm{H}_{2}$ evolution photocatalyst $\left(\mathrm{H}_{2}\right.$ photocatalyst) and Pt-deposited tungsten trioxide $\left(\mathrm{Pt} / \mathrm{WO}_{3}\right)$ as an $\mathrm{O}_{2}$ evolution photocatalyst $\left(\mathrm{O}_{2}\right.$ photocatalyst $) .{ }^{20}$ To date, numerous Z-scheme systems consisting of various $\mathrm{H}_{2}$ and $\mathrm{O}_{2}$ photocatalysts have been reported. ${ }^{21-23}$

Despite the potential of Z-scheme systems for photocatalytic water splitting, most systems reported to date are only able to utilize visible light up to a wavelength of $520 \mathrm{~nm}$. In addition, because conventional Z-scheme systems require a suitable redox mediator, such as iodate $\left(\mathrm{IO}_{3}{ }^{-}\right)$/iodide $\left(\mathrm{I}^{-}\right)$or ferric $\left(\mathrm{Fe}^{3+}\right) /$ ferrous $\left(\mathrm{Fe}^{2+}\right)$ ions, these systems are not capable of splitting "pure" water (i.e., distilled water without chemicals). Recently, solid-state Z-scheme systems that function in the absence of a redox mediator have been reported. ${ }^{24,25}$ However, because the $\mathrm{pH}$ of the system required adjustment to 3.5 using sulfuric acid $\left(\mathrm{H}_{2} \mathrm{SO}_{4}\right)$, pure-water splitting was not accomplished.

Recently, we developed novel solid-state photocatalysts by inserting silver $(\mathrm{Ag})$ as an electron mediator between zinc rhodium oxide $\left(\mathrm{ZnRh}_{2} \mathrm{O}_{4}, E_{\mathrm{g}}\right.$ of $\left.1.2 \mathrm{eV}\right)$ as an $\mathrm{H}_{2}$ photocatalyst and defective silver antimonate $\left(\mathrm{Ag}_{1-x} \mathrm{SbO}_{3-y}, E_{\mathrm{g}}\right.$ of $\left.2.7 \mathrm{eV}\right)$ or bismuth vanadium oxide $\left(\mathrm{Bi}_{4} \mathrm{~V}_{2} \mathrm{O}_{11}\right)$ as an $\mathrm{O}_{2}$ photocatalyst $\left(\mathrm{ZnRh}_{2} \mathrm{O}_{4} / \mathrm{Ag} / \mathrm{Ag}_{1-x} \mathrm{SbO}_{3-y}{ }^{26}\right.$ or $\left.\mathrm{ZnRh}_{2} \mathrm{O}_{4} / \mathrm{Ag} / \mathrm{Bi}_{4} \mathrm{~V}_{2} \mathrm{O}_{11}{ }^{27}\right)$. Using these systems, overall pure-water splitting proceeded via the inserted $\mathrm{Ag}$, which mediated the transfer of photoexcited electrons from the conduction band (CB) of the $\mathrm{O}_{2}$ photocatalyst to the valence band (VB) of the $\mathrm{H}_{2}$ photocatalyst. $\mathrm{ZnRh}_{2} \mathrm{O}_{4} / \mathrm{Ag} /$ $\mathrm{Ag}_{1-x} \mathrm{SbO}_{3-y}$ and $\mathrm{ZnRh}_{2} \mathrm{O}_{4} / \mathrm{Ag} / \mathrm{Bi}_{4} \mathrm{~V}_{2} \mathrm{O}_{11}$ utilized visible light up 
to wavelengths of 545 and $700 \mathrm{~nm}$, respectively, a property that was determined by the photoactivity of $\mathrm{Ag}_{1-x} \mathrm{SbO}_{3-y}$ and $\mathrm{Bi}_{4} \mathrm{~V}_{2} \mathrm{O}_{11}$. In the previous study, we utilized polycrystalline $\mathrm{Bi}_{4} \mathrm{~V}_{2} \mathrm{O}_{11}$ ( $\mathrm{p}-\mathrm{Bi}_{4} \mathrm{~V}_{2} \mathrm{O}_{11}$ ) powder, which was prepared by a normal solidstate reaction, for the synthesis of $\mathrm{ZnRh}_{2} \mathrm{O}_{4} / \mathrm{Ag} / \mathrm{Bi}_{4} \mathrm{~V}_{2} \mathrm{O}_{11}$.

In the present study, $\mathrm{Bi}_{4} \mathrm{~V}_{2} \mathrm{O}_{11}$ powder was obtained by pulverizing single crystals of $\mathrm{Bi}_{4} \mathrm{~V}_{2} \mathrm{O}_{11}\left(\mathrm{~s}-\mathrm{Bi}_{4} \mathrm{~V}_{2} \mathrm{O}_{11}\right)$ to form the powdered photocatalyst $\mathrm{ZnRh}_{2} \mathrm{O}_{4} / \mathrm{Ag} / \mathrm{s}-\mathrm{Bi}_{4} \mathrm{~V}_{2} \mathrm{O}_{11}$, which displayed enhanced water-splitting activity compared to $\mathrm{ZnRh}_{2} \mathrm{O}_{4} / \mathrm{Ag} / \mathrm{p}$ $\mathrm{Bi}_{4} \mathrm{~V}_{2} \mathrm{O}_{11}$. Notably, $\mathrm{ZnRh}_{2} \mathrm{O}_{4} / \mathrm{Ag} / \mathrm{s}-\mathrm{Bi}_{4} \mathrm{~V}_{2} \mathrm{O}_{11}$ was able to utilize visible light up to wavelengths of $740 \mathrm{~nm}$, which represents nearly the entire visible light spectrum and to our knowledge, is the longest wavelength reported to date (ESI $1 \dagger$ ).

\section{Experimental}

\section{Sample preparation}

A melting-slow cooling method was applied to grow single crystals of $\mathrm{Bi}_{4} \mathrm{~V}_{2} \mathrm{O}_{11}\left(\mathrm{~s}^{-}-\mathrm{Bi}_{4} \mathrm{~V}_{2} \mathrm{O}_{11}\right)$ by melting $\left(940{ }^{\circ} \mathrm{C}\right)$ and slow cooling $\left(4{ }^{\circ} \mathrm{C} \mathrm{h}^{-1}\right.$ to $\left.740{ }^{\circ} \mathrm{C}\right)$ of stoichiometric mixtures of commercial bismuth oxide $\left(\mathrm{Bi}_{2} \mathrm{O}_{3}\right.$, purity $99.9 \%$; Kanto Kagaku) and vanadium oxide $\left(\mathrm{V}_{2} \mathrm{O}_{5}\right.$, purity $99.0 \%$; Kanto Kagaku) powders. ${ }^{28}$ The obtained single crystals adopted a thin platelike sheet structure and had a thickness of $\sim 0.2 \mathrm{~mm}$ and transverse dimensions of $\sim 1 \mathrm{~mm} \times 2 \mathrm{~mm}$. The thin sheets of $\mathrm{Bi}_{4} \mathrm{~V}_{2} \mathrm{O}_{11}$ were used directly for Laue photography and X-ray diffractometer analyses, and were further pulverized for use in all other experiments.

$\mathrm{ZnRh}_{2} \mathrm{O}_{4}$ powders were synthesized using a solid-state reaction method. Briefly, stoichiometric amounts of commercial zinc oxide (ZnO, purity 99.0\%; Kanto Kagaku) and rhodium oxide $\left(\mathrm{Rh}_{2} \mathrm{O}_{3}\right.$, purity 99.9\%; Kanto Kagaku) powders were mixed and calcined at $1000{ }^{\circ} \mathrm{C}$ for $24 \mathrm{~h}$ and the obtained powders were thoroughly ground. As a reference, the $\mathrm{Bi}_{2} \mathrm{O}_{3}$ and $\mathrm{V}_{2} \mathrm{O}_{5}$ powders were mixed and calcined at $850{ }^{\circ} \mathrm{C}$ for $8 \mathrm{~h}$ to prepare poly-crystal powders of $\mathrm{Bi}_{4} \mathrm{~V}_{2} \mathrm{O}_{11}\left(\mathrm{p}-\mathrm{Bi}_{4} \mathrm{~V}_{2} \mathrm{O}_{11}\right)$, which were thoroughly ground prior to experimental use.

A powdered heterojunction photocatalyst composed of $\mathrm{ZnRh}_{2} \mathrm{O}_{4}, \mathrm{~s}-\mathrm{Bi}_{4} \mathrm{~V}_{2} \mathrm{O}_{11}$, and $\mathrm{Ag}\left(\mathrm{ZnRh}_{2} \mathrm{O}_{4} / \mathrm{Ag} / \mathrm{s}-\mathrm{Bi}_{4} \mathrm{~V}_{2} \mathrm{O}_{11}\right)$ was prepared using the following simple method. ${ }^{27} \mathrm{ZnRh}_{2} \mathrm{O}_{4}, \mathrm{Ag}_{2} \mathrm{O}$, and $\mathrm{s}-\mathrm{Bi}_{4} \mathrm{~V}_{2} \mathrm{O}_{11}$ powders were mixed at a molar ratio of $1: 1: 1.2$ in an identical manner to that described above. The mixed powders were pressed into pellets by applying a force of $60 \mathrm{kN}$, and the pellets were then heated at $750{ }^{\circ} \mathrm{C}$ for $2 \mathrm{~h}$. The pellets were ground into a fine powder, which was soaked in an aqueous solution $(50 \mathrm{~mL})$ of $3 \mathrm{M}$ nitric acid $\left(\mathrm{HNO}_{3}\right.$, Kanto Kagaku) for $15 \mathrm{~min}$. The powder was filtered and thoroughly washed with distilled water, and was then dried at $65{ }^{\circ} \mathrm{C}$ for $12 \mathrm{~h}$. As a reference, $\mathrm{ZnRh}_{2} \mathrm{O}_{4} / \mathrm{Ag} / \mathrm{p}-\mathrm{Bi}_{4} \mathrm{~V}_{2} \mathrm{O}_{11}$ was also prepared using the same procedure. $^{27}$

\section{Characterization}

A Laue camera (SA-HFM3, Rigaku) was used for the characterization of $\mathrm{Bi}_{4} \mathrm{~V}_{2} \mathrm{O}_{11}$ single crystals. The crystal structures of the single crystals and powder obtained by pulverizing single crystals were determined by X-ray diffraction (XRD) using a PW-1700 X-ray diffractometer (PANalytical). The structure of the $\mathrm{ZnRh}_{2} \mathrm{O}_{4} / \mathrm{Ag} /$ $\mathrm{Bi}_{4} \mathrm{~V}_{2} \mathrm{O}_{11}$ powder was also determined by XRD. The BrunauerEmmett-Teller (BET) surface area was determined using a nitrogen adsorption apparatus (Micromeritics, TriStar 3000, Shimadzu). UV-visible absorption (UV-vis) spectra were obtained by the diffuse reflection method using a V-650 spectrometer (Jasco) with barium sulfate $\left(\mathrm{BaSO}_{4}\right)$ as the reflectance standard. Photoacoustic (PA) spectroscopy measurements were conducted in a nitrogen atmosphere under monochromic light generated from a $300 \mathrm{~W}$ xenon (Xe) lamp (LX300, Eagle) equipped with a monochromator (CT-101T, Jasco) and modulated by a light chopper at $80 \mathrm{~Hz}$. The PA signal was amplified and monitored using a digital lock-in amplifier (LI5640, NF). ${ }^{29,30}$ A scanning electron microscope (SEM, JSM-6500F, JEOL Ltd) was used to observe the morphology of the prepared photocatalysts. A scanning transmission electron microscope (STEM, Tecnai Osiris, FEI) was also utilized with element maps obtained by energy-dispersive X-ray spectrometry (EDS).

\section{$\mathrm{O}_{2}$ evolution activity by the half reaction of water}

Action spectra for $\mathrm{O}_{2}$ evolution were measured in $3 \mathrm{~mL}$ water containing either $\mathrm{s}-\mathrm{Bi}_{4} \mathrm{~V}_{2} \mathrm{O}_{11}$ or $\mathrm{p}-\mathrm{Bi}_{4} \mathrm{~V}_{2} \mathrm{O}_{11}$ powder $(30 \mathrm{mg})$ and $\mathrm{Ce}^{4+}$ (cerium sulfate $\left(\mathrm{Ce}\left(\mathrm{SO}_{4}\right)_{2}\right), 0.1 \mathrm{~mol} \mathrm{~L}^{-1}$; Kanto Kagaku) as a sacrificial agent. The $\mathrm{pH}$ of the solution was not adjusted prior to the spectral measurements, which were performed with constant stirring using a magnetic stirrer and under illumination with monochromatic light $(570 \pm 5$ to $750 \pm 5 \mathrm{~nm})$ generated from a diffraction grating-type illuminator (CRM-FD, Jasco) equipped with a $300 \mathrm{~W}$ Xe lamp (C2578-02, Hamamatsu Photonics). Higher-order diffracted light was cut off using an appropriate glass filter. The amount of evolved $\mathrm{O}_{2}$ was monitored using a gas chromatograph (GC-8A, Shimadzu). The wavelength dependence of the AQE was then evaluated. AQE values for $\mathrm{O}_{2}$ evolution were calculated using the equation: $\mathrm{AQE}(\%)=100 \times 4 \times \mathrm{O}_{2}$ evolution rate/incident photon rate, because $\mathrm{O}_{2}$ evolution is represented by the formula: $2 \mathrm{H}_{2} \mathrm{O}+4 \mathrm{~h}^{+} \rightarrow \mathrm{O}_{2}+4 \mathrm{H}^{+}$.

\section{Water-splitting reactions}

To evaluate the photocatalytic activity, $\mathrm{ZnRh}_{2} \mathrm{O}_{4} / \mathrm{Ag} / \mathrm{s}-\mathrm{Bi}_{4} \mathrm{~V}_{2} \mathrm{O}_{11}$ or $\mathrm{ZnRh}_{2} \mathrm{O}_{4} / \mathrm{Ag} / \mathrm{p}-\mathrm{Bi}_{4} \mathrm{~V}_{2} \mathrm{O}_{11}$ composite powder $(60 \mathrm{mg})$ was suspended in $12 \mathrm{~mL}$ pure water ( $\mathrm{pH}$ unadjusted) under an argon atmosphere (50 $\mathrm{kPa})$ and constant stirring using a magnetic stirrer. A Xe lamp (LA-251Xe, Hayashi Tokei) equipped with an optical filter (irradiated wavelength $>420 \mathrm{~nm}$; Y-44, Hoya) and light-emitting diode (LED) lamps with wavelengths of 545 (LEDH60-545, Hamamatsu Photonics), 610 (LEDH60-600, Hamamatsu Photonics), 700 (LEDH60-700, Hamamatsu Photonics), and $740 \mathrm{~nm}$ (LEDH60740, Hamamatsu Photonics) were used for light irradiation. The amount of evolved $\mathrm{H}_{2}$ and $\mathrm{O}_{2}$ was monitored using an online GC-8A gas chromatograph. AQE values were calculated using the amount of evolved $\mathrm{O}_{2}$ in the same way as described above.

Photocatalytic overall water-splitting by $\mathrm{ZnRh}{ }_{2} \mathrm{O}_{4} / \mathrm{Ag} / \mathrm{s}-\mathrm{Bi}_{4} \mathrm{~V}_{2} \mathrm{O}_{11}$ was also evaluated using pure water containing 33\% isotopic water $\left(\mathrm{H}_{2}{ }^{18} \mathrm{O}\right.$, purity $97 \mathrm{~atm} \%{ }^{18} \mathrm{O}$; Sigma-Aldrich $)$ under light irradiation emitted from the $740 \mathrm{~nm}$ LED. The evolved gas was detected using 
a gas chromatograph/mass spectrometer (GC/MS; GCMS-QP 2010 Ultra, Shimadzu), which was operated in the selectiveion mode and monitored ions with masses of $28\left({ }^{14} \mathrm{~N}^{14} \mathrm{~N}\right), 32$ $\left({ }^{16} \mathrm{O}^{16} \mathrm{O}\right), 34\left({ }^{18} \mathrm{O}^{16} \mathrm{O}\right)$, and $36\left({ }^{18} \mathrm{O}^{18} \mathrm{O}\right)$. The measurement conditions, other than those used for pure water containing isotropic water, were the same as those used in the photocatalytic overall purewater splitting tests.

\section{Results and discussion}

\section{Characterization}

A back-reflection Laue pattern taken from normal to the plate surface of a $\mathrm{Bi}_{4} \mathrm{~V}_{2} \mathrm{O}_{11}$ single crystal is shown in Fig. S1 (ESI $2 \dagger$ ). The distribution of diffraction spots revealed that $\mathrm{Bi}_{4} \mathrm{~V}_{2} \mathrm{O}_{11}$ was a single crystal. XRD patterns for a single crystal of $\mathrm{Bi}_{4} \mathrm{~V}_{2} \mathrm{O}_{11}$ and the powders obtained by pulverizing the single crystals of $\mathrm{Bi}_{4} \mathrm{~V}_{2} \mathrm{O}_{11}$ were also determined (Fig. 1). For the single $\mathrm{Bi}_{4} \mathrm{~V}_{2} \mathrm{O}_{11}$ crystal in the direction normal to the plate surface, only (00l) peaks were detected, indicating that the plate face of the single crystal corresponded to the (001) plane. This assumption is reasonable because $\mathrm{Bi}_{4} \mathrm{~V}_{2} \mathrm{O}_{11}$ is an Aurivillius-type bismuth layer-structured oxide (BLSO) and consists of alternating $\left(\mathrm{Bi}_{2} \mathrm{O}_{2}\right)^{2+}$ layers and oxygen-deficient pseudo-perovskite blocks of $\left(\mathrm{VO}_{3.5} \square_{0.5}\right)^{2-}$ along the $c$-axis. ${ }^{31}$ Thus, because the growth rate of BLSO crystals in the $c$-axis direction is much lower than that along the $a(b)$-axis, single crystals of $\mathrm{Bi}_{4} \mathrm{~V}_{2} \mathrm{O}_{11}$ in the form of thin plate-like sheets with plate faces in the (001) plane were obtained. For the pulverized powder, all of the observed XRD peaks could be assigned to those for $\mathrm{Bi}_{4} \mathrm{~V}_{2} \mathrm{O}_{11}$. The BET surface areas of pulverized $\mathrm{s}-\mathrm{Bi}_{4} \mathrm{~V}_{2} \mathrm{O}_{11}$ and as-prepared $\mathrm{ZnRh}_{2} \mathrm{O}_{4}$ powders were 0.179 and $3.60 \mathrm{~m}^{2} \mathrm{~g}^{-1}$, respectively.

$\mathrm{UV}$-vis absorption and PA spectra of $\mathrm{s}-\mathrm{Bi}_{4} \mathrm{~V}_{2} \mathrm{O}_{11}$ are shown in Fig. 2. Although the UV-vis absorption intensity decreased with increasing wavelength, relatively strong intensity was observed in longer wavelength regions. In contrast, the PA absorption of $\mathrm{s}-\mathrm{Bi}_{4} \mathrm{~V}_{2} \mathrm{O}_{11}$ decreased with increasing wavelength, a property that reflects true photoabsorption, ${ }^{30}$ which will be discussed later.

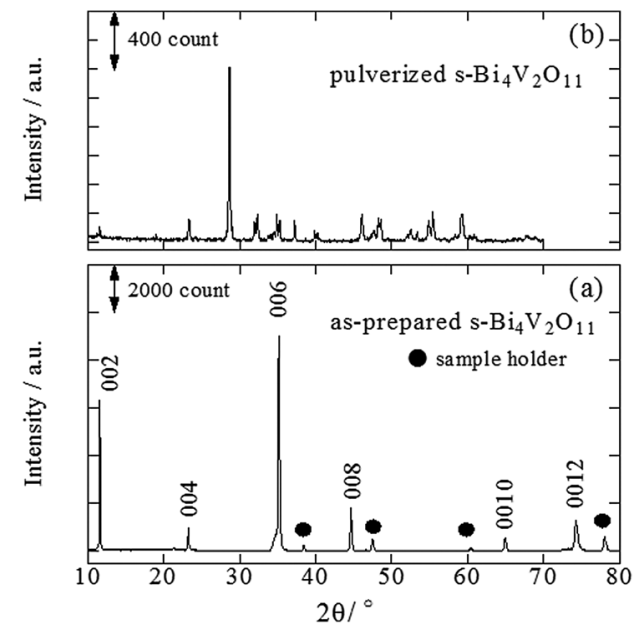

Fig. 1 XRD patterns of the as-prepared (a) and pulverized $\mathrm{s}-\mathrm{Bi}_{4} \mathrm{~V}_{2} \mathrm{O}_{11}$ (b).

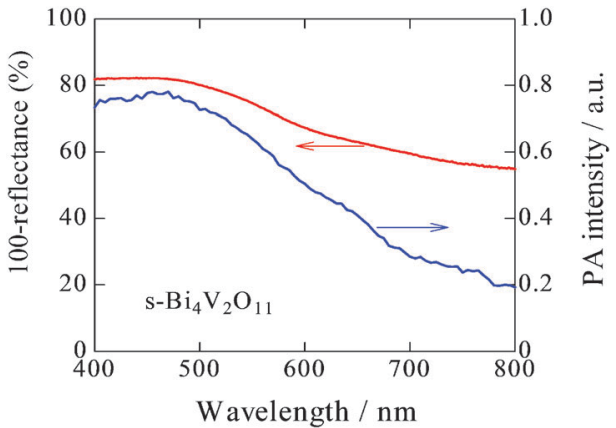

Fig. 2 UV-visible absorption and PA spectra of $\mathrm{s}-\mathrm{Bi}_{4} \mathrm{~V}_{2} \mathrm{O}_{11}$.

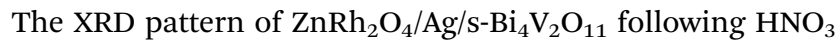
treatment is shown in Fig. 3. The XRD peaks mainly corresponded to two phases originating from $\mathrm{ZnRh}_{2} \mathrm{O}_{4}$ and $\mathrm{Bi}_{4} \mathrm{~V}_{2} \mathrm{O}_{11}$, although trace peaks attributable to a type of $\mathrm{Ag}$ oxide, such as $\mathrm{AgVO}_{3}$, were also detected. However, Ag peaks were not observed. This result is plausible because most of the $\mathrm{Ag}$ was likely removed by the $\mathrm{HNO}_{3}$ treatment and the amount of $\mathrm{Ag}$ remaining in the composite was below the limit of detection.

UV-vis absorption spectra of $\mathrm{s}-\mathrm{Bi}_{4} \mathrm{~V}_{2} \mathrm{O}_{11}, \mathrm{ZnRh}_{2} \mathrm{O}_{4}$, and $\mathrm{ZnRh}_{2} \mathrm{O}_{4} / \mathrm{Ag} / \mathrm{s}-\mathrm{Bi}_{4} \mathrm{~V}_{2} \mathrm{O}_{11}$ with and without $\mathrm{HNO}_{3}$ treatment are shown in Fig. 4. As can be seen in the spectra, untreated $\mathrm{ZnRh}_{2} \mathrm{O}_{4} / \mathrm{Ag} / \mathrm{s}-\mathrm{Bi}_{4} \mathrm{~V}_{2} \mathrm{O}_{11}$ showed greater absorption at wavelengths

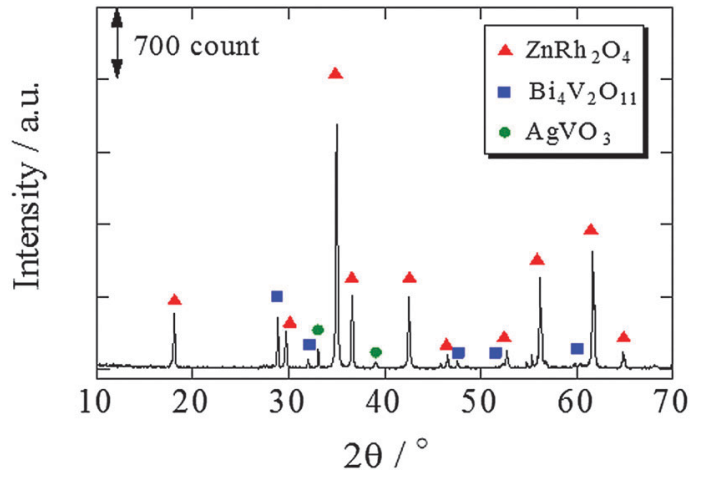

Fig. 3 XRD patterns of $\mathrm{ZnRh}_{2} \mathrm{O}_{4} / \mathrm{Ag} / \mathrm{s}-\mathrm{Bi}_{4} \mathrm{~V}_{2} \mathrm{O}_{11}$ after $\mathrm{HNO}_{3}$ treatment

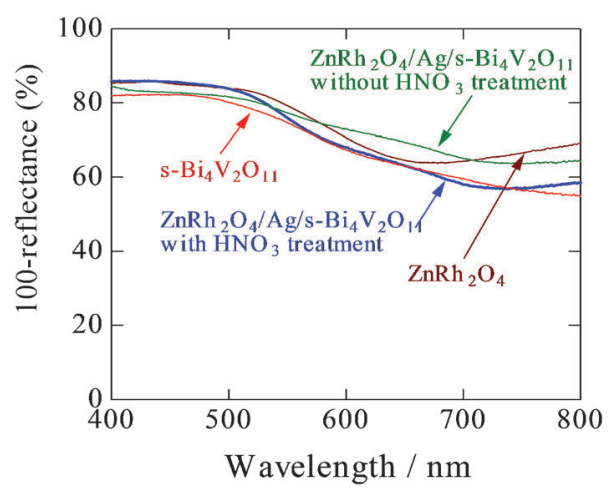

Fig. 4 UV-visible absorption spectra of $\mathrm{s}-\mathrm{Bi}_{4} \mathrm{~V}_{2} \mathrm{O}_{11}, \mathrm{ZnRh}_{2} \mathrm{O}_{4}$, and $\mathrm{ZnRh}_{2} \mathrm{O}_{4} / \mathrm{Ag} / \mathrm{s}-\mathrm{Bi}_{4} \mathrm{~V}_{2} \mathrm{O}_{11}$ (with and without $\mathrm{HNO}_{3}$ treatment). 

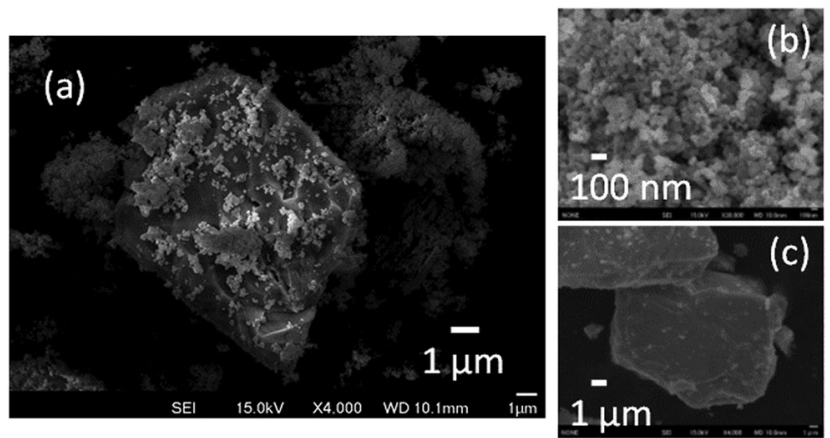

Fig. $5 \mathrm{SEM}$ images of $\mathrm{ZnRh}_{2} \mathrm{O}_{4} / \mathrm{Ag} / \mathrm{s}-\mathrm{Bi}_{4} \mathrm{~V}_{2} \mathrm{O}_{11}$ powder after $\mathrm{HNO}_{3}$ treatment (a), as-prepared $\mathrm{ZnRh}_{2} \mathrm{O}_{4}$ (b) and pulverized $\mathrm{s}-\mathrm{Bi}_{4} \mathrm{~V}_{2} \mathrm{O}_{11}$ (c) powders.

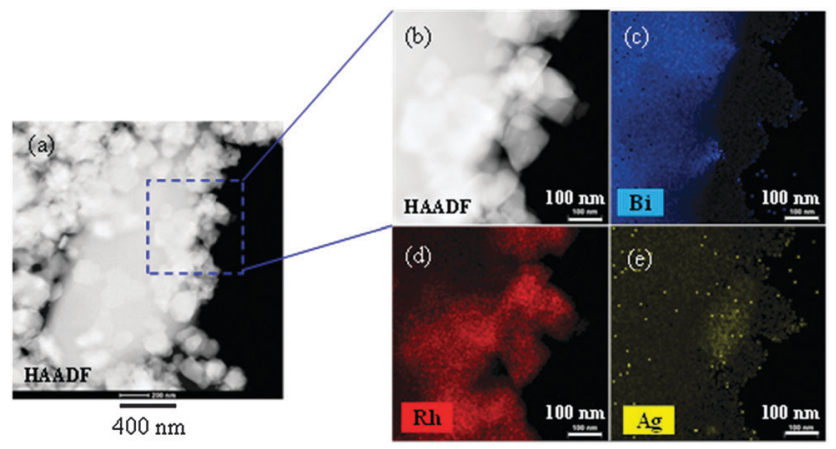

Fig. 6 STEM images of $\mathrm{ZnRh}_{2} \mathrm{O}_{4} / \mathrm{Ag} / \mathrm{s}-\mathrm{Bi}_{4} \mathrm{~V}_{2} \mathrm{O}_{11}$ after $\mathrm{HNO}_{3}$ treatment STEM image (a), its enlargement (b), and EDS element maps (c-e), in which blue (c), red (d), and yellow (e) colors correspond to $\mathrm{Bi}, \mathrm{Rh}$, and $\mathrm{Ag}$, respectively.

longer than $\sim 600 \mathrm{~nm}$ compared to $\mathrm{HNO}_{3}$-treated $\mathrm{ZnRh}_{2} \mathrm{O}_{4} / \mathrm{Ag} /$ s- $\mathrm{Bi}_{4} \mathrm{~V}_{2} \mathrm{O}_{11}$. After the $\mathrm{HNO}_{3}$ treatment, the absorption by $\mathrm{ZnRh}_{2} \mathrm{O}_{4} /$ $\mathrm{Ag} / \mathrm{s}-\mathrm{Bi}_{4} \mathrm{~V}_{2} \mathrm{O}_{11}$ at wavelengths longer than $\sim 600 \mathrm{~nm}$ decreased and the spectral profile was in between those of $\mathrm{ZnRh}_{2} \mathrm{O}_{4}$ and $\mathrm{s}-\mathrm{Bi}_{4} \mathrm{~V}_{2} \mathrm{O}_{11}$. Photos of pulverized s- $\mathrm{Bi}_{4} \mathrm{~V}_{2} \mathrm{O}_{11}$, as-prepared $\mathrm{ZnRh}_{2} \mathrm{O}_{4}$, and $\mathrm{ZnRh}_{2} \mathrm{O}_{4} / \mathrm{Ag} / \mathrm{p}-\mathrm{Bi}_{4} \mathrm{~V}_{2} \mathrm{O}_{11}$ after $\mathrm{HNO}_{3}$ treatment are shown in Fig. S2 (ESI $3 \dagger$ ).

In an SEM image of $\mathrm{HNO}_{3}$-treated $\mathrm{ZnRh}_{2} \mathrm{O}_{4} / \mathrm{Ag} / \mathrm{s}-\mathrm{Bi}_{4} \mathrm{~V}_{2} \mathrm{O}_{11}$ powder, small $\mathrm{ZnRh}_{2} \mathrm{O}_{4}(\sim 50-100 \mathrm{~nm})$ and large $\mathrm{Bi}_{4} \mathrm{~V}_{2} \mathrm{O}_{11}$ particles $(\sim 10 \mu \mathrm{m})$ were clearly visible (Fig. $5 \mathrm{a})$. Notably, the particle size of each photocatalytic material was identical to that before preparation of the heterojunction photocatalyst (Fig. 5b and c). STEM imaging and EDS-based elemental mapping of $\mathrm{HNO}_{3}$-treated $\mathrm{ZnRh}_{2} \mathrm{O}_{4} / \mathrm{Ag} / \mathrm{Bi}_{4} \mathrm{~V}_{2} \mathrm{O}_{11}$ were also performed (Fig. 6a-e). As was observed in the SEM image, the $\mathrm{s}-\mathrm{Bi}_{4} \mathrm{~V}_{2} \mathrm{O}_{11}$ and $\mathrm{ZnRh}_{2} \mathrm{O}_{4}$ particles were clearly distinguishable (Fig. 6a and b) based on size differences. In addition, $\mathrm{Ag}$ was distributed (Fig. 6e) between the areas of Bi (Fig. 6c) and Rh (Fig. 6d), indicating that the $\mathrm{Ag}$ was inserted between the particles of $\mathrm{ZnRh}_{2} \mathrm{O}_{4}$ and $\mathrm{Bi}_{4} \mathrm{~V}_{2} \mathrm{O}_{11}$.

\section{Action spectra for $\mathrm{O}_{2}$ evolution of $\mathrm{Bi}_{4} \mathrm{~V}_{2} \mathrm{O}_{11}$}

To examine and compare the activity of s- $\mathrm{Bi}_{4} \mathrm{~V}_{2} \mathrm{O}_{11}$ with that of p- $-\mathrm{Bi}_{4} \mathrm{~V}_{2} \mathrm{O}_{11}$ as an $\mathrm{O}_{2}$ evolution photocatalyst, the half reaction of water over $\mathrm{s}-\mathrm{Bi}_{4} \mathrm{~V}_{2} \mathrm{O}_{11}$ and $\mathrm{p}-\mathrm{Bi}_{4} \mathrm{~V}_{2} \mathrm{O}_{11}$ was evaluated using an

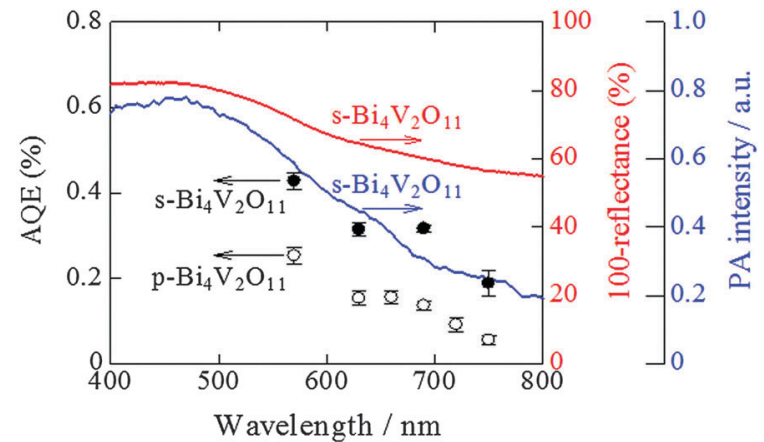

Fig. 7 Action spectra for $\mathrm{O}_{2}$ evolution by the half reaction of water over $\mathrm{s}-\mathrm{Bi}_{4} \mathrm{~V}_{2} \mathrm{O}_{11}$ (solid circles) and $\mathrm{p}-\mathrm{Bi}_{4} \mathrm{~V}_{2} \mathrm{O}_{11}$ (open circles) in the presence of $\mathrm{Ce}^{4+}$. The UV-visible absorption (red line) and PA (blue line) spectra of $\mathrm{s}-\mathrm{Bi}_{4} \mathrm{~V}_{2} \mathrm{O}_{11}$ are also shown.

aqueous $\mathrm{Ce}\left(\mathrm{SO}_{4}\right)_{2}$ solution containing $\mathrm{Ce}^{4+}$ as the sacrificial agent (Fig. 7). Aqueous $\mathrm{Ce}\left(\mathrm{SO}_{4}\right)_{2}$ is yellowish and transparent, and absorbs visible light up to a wavelength of $\sim 550 \mathrm{~nm}$. Thus, we irradiated $\mathrm{s}-\mathrm{Bi}_{4} \mathrm{~V}_{2} \mathrm{O}_{11}$ and $\mathrm{p}-\mathrm{Bi}_{4} \mathrm{~V}_{2} \mathrm{O}_{11}$ with light at wavelengths of longer than $570 \mathrm{~nm}$ and found that both materials were able to produce $\mathrm{O}_{2}$ under visible light up to $750 \mathrm{~nm}$. This

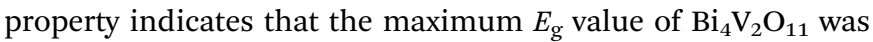
$1.65 \mathrm{eV}$. The AQE values of $\mathrm{s}-\mathrm{Bi}_{4} \mathrm{~V}_{2} \mathrm{O}_{11}$ were $\sim 2$-3-fold larger than those of $\mathrm{p}-\mathrm{Bi}_{4} \mathrm{~V}_{2} \mathrm{O}_{11}$. As s- $\mathrm{Bi}_{4} \mathrm{~V}_{2} \mathrm{O}_{11}$ is considered to have higher crystallinity and anisotropy than $\mathrm{p}-\mathrm{Bi}_{4} \mathrm{~V}_{2} \mathrm{O}_{11}$, photogenerated electrons and holes would therefore have enhanced mobility and separation (Fig. S3 in the ESI $4 \dagger$ ).

It should be noted that the $\mathrm{AQE}$ values for $\mathrm{O}_{2}$ evolution by $s-\mathrm{Bi}_{4} \mathrm{~V}_{2} \mathrm{O}_{11}$ were not consistent with the corresponding UV-vis absorption spectrum. A discrepancy between AQE values and absorption is frequently encountered, particularly for absorption in longer wavelength regions. ${ }^{32,33}$ In contrast, the AQE values for $\mathrm{O}_{2}$ evolution coincided well with the PA absorption spectrum, which is generally accepted as corresponding to true absorption. ${ }^{30}$ Thus, it can be concluded that the $\mathrm{O}_{2}$ evolution reaction proceeded via photoinduced band excitation (Fig. S3 in the ESI $4 \dagger$ ). This excitation can be assigned to that originating from the $\mathrm{VB}$, which contains $\mathrm{O} 2 \mathrm{p}$ and $\mathrm{Bi}$ 6s orbitals from the $\left(\mathrm{Bi}_{2} \mathrm{O}_{2}\right)^{2+}$ layers, to the $\mathrm{CB}$, which is composed of a mixture of $\mathrm{Bi} 6 \mathrm{p}$ orbitals and antibonding $\mathrm{O} 2 \mathrm{p}$ and $\mathrm{V} 3 \mathrm{~d}$ orbitals of $\left(\mathrm{VO}_{3.5} \square_{0.5}\right)^{2-}$ blocks. ${ }^{34}$ The obtained $E_{\mathrm{g}}$ value $(1.65 \mathrm{eV})$ is smaller than the previously reported values of $\sim 1.96-2.2 \mathrm{eV}^{34-37}$ Although the reason for this difference is unclear, it may be attributable to the greater amount of oxygen defects in our samples (larger than 0.5 in $\left.\mathrm{VO}_{3.5} \square_{0.5}\right)^{2-}$. The oxygen defect states form an isolated band below the CB bottom, whose width increases with the concentration of the defects, reaches the $\mathrm{CB}$ bottom, and finally starts to overlap with the $\mathrm{CB}$, similar to the case of $\mathrm{TiO}_{2}{ }^{38}$ In addition, it was reported that the band-gap of $\mathrm{Bi}_{4} \mathrm{~V}_{2} \mathrm{O}_{11}$ changes depending on the morphologies and preparation procedures. ${ }^{37}$

We previously reported that $\mathrm{ZnRh}_{2} \mathrm{O}_{4}$ can utilize visible light at wavelengths up to $770 \mathrm{~nm}$ and is also likely capable of utilizing infrared light for $\mathrm{H}_{2}$ evolution. ${ }^{32}$ Thus, $\mathrm{ZnRh}_{2} \mathrm{O}_{4} / \mathrm{Ag} /$ $\mathrm{s}-\mathrm{Bi}_{4} \mathrm{~V}_{2} \mathrm{O}_{11}$ is expected to be sensitive to visible light up to at least $750 \mathrm{~nm}$. 


\section{Overall water splitting}

The time courses of $\mathrm{H}_{2}$ and $\mathrm{O}_{2}$ evolution from pure water by $\mathrm{ZnRh}_{2} \mathrm{O}_{4} / \mathrm{Ag} / \mathrm{s}_{-}-\mathrm{Bi}_{4} \mathrm{~V}_{2} \mathrm{O}_{11}$ powder under visible-light irradiation $(>420 \mathrm{~nm})$ are shown in Fig. S4 (ESI $5 \dagger)$. Under these conditions, the linear generation of $\mathrm{H}_{2}$ and $\mathrm{O}_{2}$ at a molar ratio of 2 to 1 was observed. We performed this experiment with newly prepared powders and observed similar $\mathrm{H}_{2}$ and $\mathrm{O}_{2}$ evolution rates, confirming the reproducibility of the data. In addition, we characterized the prepared $\mathrm{ZnRh}_{2} \mathrm{O}_{4} / \mathrm{Ag} / \mathrm{s}-\mathrm{Bi}_{4} \mathrm{~V}_{2} \mathrm{O}_{11}$ powder after the water-splitting reaction under the same conditions as used in Fig. S4 (ESI $\dagger$ ) by XRD and STEM/EDS and found that the sample did not appear to have changed (Fig. S5 and S6 in the ESI $5 \dagger$ ). We also confirmed that the water-splitting reaction did not occur in the dark (data not shown).

The time courses of $\mathrm{H}_{2}$ and $\mathrm{O}_{2}$ evolution resulting from water splitting by $\mathrm{ZnRh}_{2} \mathrm{O}_{4} / \mathrm{Ag} / \mathrm{s}-\mathrm{Bi}_{4} \mathrm{~V}_{2} \mathrm{O}_{11}$ and $\mathrm{ZnRh}_{2} \mathrm{O}_{4} / \mathrm{Ag} /$ $\mathrm{p}-\mathrm{Bi}_{4} \mathrm{~V}_{2} \mathrm{O}_{11}$ under irradiation with monochromic light with wavelengths of $545,610,700$, and $740 \mathrm{~nm}$ were next measured (Fig. 8a-d). Under all conditions, $\mathrm{ZnRh}_{2} \mathrm{O}_{4} / \mathrm{Ag} / \mathrm{s}-\mathrm{Bi}_{4} \mathrm{~V}_{2} \mathrm{O}_{11}$ evolved $\mathrm{H}_{2}$ and $\mathrm{O}_{2}$ from water at a molar ratio of 2 to 1 . The $\mathrm{H}_{2}$ and $\mathrm{O}_{2}$ evolution rates of $\mathrm{ZnRh}_{2} \mathrm{O}_{4} / \mathrm{Ag} / \mathrm{s}-\mathrm{Bi}_{4} \mathrm{~V}_{2} \mathrm{O}_{11}$ irradiated with $610 \mathrm{~nm}$ and $700 \mathrm{~nm}$ light were $\sim$ two- and three-fold larger, respectively, than those of $\mathrm{ZnRh}_{2} \mathrm{O}_{4} / \mathrm{Ag} / \mathrm{p}-\mathrm{Bi}_{4} \mathrm{~V}_{2} \mathrm{O}_{11}$. In addition, the induction period for linear $\mathrm{H}_{2}$ and $\mathrm{O}_{2}$ evolution was shortened. Upon irradiation with $740 \mathrm{~nm}$ light, $\mathrm{ZnRh}_{2} \mathrm{O}_{4} /$ $\mathrm{Ag} / \mathrm{s}-\mathrm{Bi}_{4} \mathrm{~V}_{2} \mathrm{O}_{11}$ evolved $\mathrm{H}_{2}$ and $\mathrm{O}_{2}$ at a ratio of 2 to 1 after the induction period, whereas $\mathrm{ZnRh}_{2} \mathrm{O}_{4} / \mathrm{Ag} / \mathrm{p}-\mathrm{Bi}_{4} \mathrm{~V}_{2} \mathrm{O}_{11}$ only produced a trace amount of $\mathrm{H}_{2}$. Thus, overall water splitting induced by $740 \mathrm{~nm}$ light was only achieved with $\mathrm{ZnRh}_{2} \mathrm{O}_{4} / \mathrm{Ag} /$ $\mathrm{s}-\mathrm{Bi}_{4} \mathrm{~V}_{2} \mathrm{O}_{11}$ and was attributable to the enhanced $\mathrm{O}_{2}$-evolution
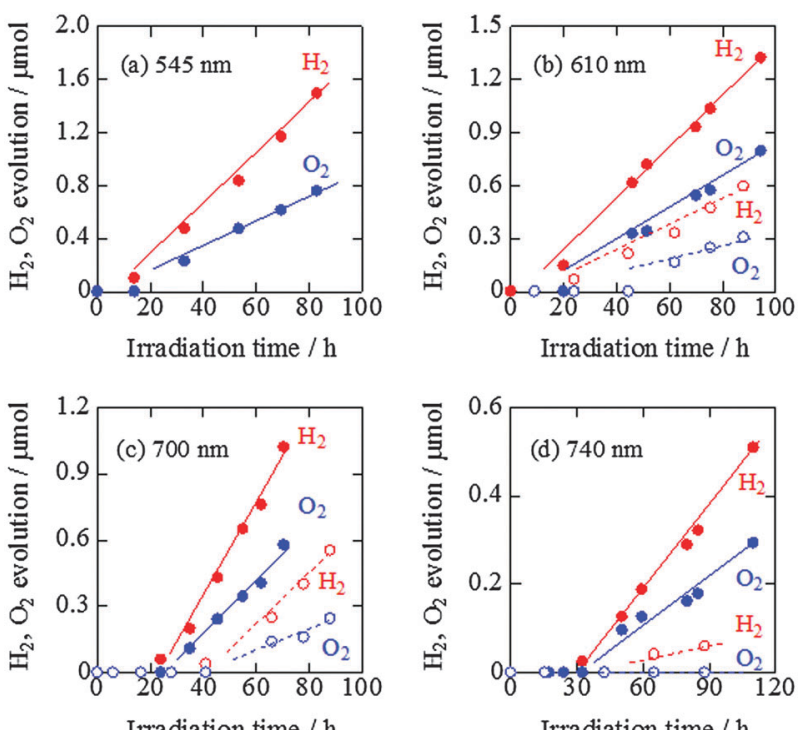

Irradiation time / $\mathrm{h}$

Irradiation time / $\mathrm{h}$

Fig. 8 Time courses of $\mathrm{H}_{2}$ and $\mathrm{O}_{2}$ evolution resulting from water splitting by $\mathrm{ZnRh}_{2} \mathrm{O}_{4} / \mathrm{Ag} / \mathrm{s}-\mathrm{Bi}_{4} \mathrm{~V}_{2} \mathrm{O}_{11}$ (closed circles with solid lines) and $\mathrm{ZnRh}_{2} \mathrm{O}_{4} /$ $\mathrm{Ag} / \mathrm{p}-\mathrm{Bi}_{4} \mathrm{~V}_{2} \mathrm{O}_{11}$ (open circles with broken lines) under irradiation with $545 \mathrm{~nm}$ LED (a), $610 \mathrm{~nm}$ LED (b), $700 \mathrm{~nm}$ LED (c), and $740 \mathrm{~nm}$ LED light (d). The $\mathrm{H}_{2}$ and $\mathrm{O}_{2}$ evolution data of $\mathrm{ZnRh}_{2} \mathrm{O}_{4} / \mathrm{Ag} / \mathrm{p}-\mathrm{Bi}_{4} \mathrm{~V}_{2} \mathrm{O}_{11}$ with $610 \mathrm{~nm}$ LED and $700 \mathrm{~nm}$ LED light are cited from ref. 27. activity of $\mathrm{s}-\mathrm{Bi}_{4} \mathrm{~V}_{2} \mathrm{O}_{11}$. Although the reason for the delay in $\mathrm{H}_{2}$ and $\mathrm{O}_{2}$ evolution is unclear, this phenomenon has been observed with other materials. ${ }^{27}$ The delay might be due to existing defects, ${ }^{39}$ redox reactions other than water-splitting reactions, ${ }^{39-42}$ reconstruction of surface states, ${ }^{43}$ or adsorption of $\mathrm{H}_{2}$ and $\mathrm{O}_{2}$ molecules on the photocatalyst surface. ${ }^{43,44}$ However, the delay can be shortened by enhancing the activity.

As shown in Fig. 7, the AQE value of $\mathrm{s}-\mathrm{Bi}_{4} \mathrm{~V}_{2} \mathrm{O}_{11}$ for $\mathrm{O}_{2}$ was $\sim 0.2 \%$ even at $750 \mathrm{~nm}$ and $\mathrm{s}-\mathrm{Bi}_{4} \mathrm{~V}_{2} \mathrm{O}_{11}$ was expected to evolve $\mathrm{O}_{2}$ under the entire range of visible light $(\sim 770 \mathrm{~nm})$. Thus, further enhancement of $\mathrm{O}_{2}$ evolution activity by $\mathrm{s}-\mathrm{Bi}_{4} \mathrm{~V}_{2} \mathrm{O}_{11}$ would allow $\mathrm{ZnRh}_{2} \mathrm{O}_{4} / \mathrm{Ag} / \mathrm{s}-\mathrm{Bi}_{4} \mathrm{~V}_{2} \mathrm{O}_{11}$ to utilize the entire range of visible light and even near-infrared light, as the $E_{\mathrm{g}}$ value of $\mathrm{ZnRh}_{2} \mathrm{O}_{4}$ is $1.2 \mathrm{eV},{ }^{33}$ for the overall water-splitting.

The mechanisms of $\mathrm{O}_{2}$ evolution on $\mathrm{BiVO}_{4}(010)$ and (011) facets were previously proposed. ${ }^{45}$ On both surfaces, water molecules favorably adsorb on Bi sites. On the (010) surface, photogenerated holes induce the removal of two protons from the adsorbed water molecule in a stepwise manner, and the resulting $\mathrm{O}$ adatom obtains an electron by bonding with adjacent $\mathrm{O}$ anions to form a peroxo intermediate (Bi-O-O-V). Following the adsorption of a second water molecule at the same $\mathrm{Bi}$ site, a second $\mathrm{O}$ adatom is formed by the identical process and then obtains an electron from the nearby peroxo group, leading to the formation of a superoxo intermediate. A rapid rearrangement results in the formation of $\mathrm{O}_{2}$, which is then desorbed from the surface. On the (010) surface, the $\mathrm{V}-\mathrm{O}$ bond does not participate in the reaction, and a hydroperoxo intermediate (Bi-O-O-H) is formed after the adsorption of the second water molecule. Two protons are removed from the adsorbed water molecule in a stepwise manner, and $\mathrm{O}_{2}$ is released from the surface. For both the (010) and (011) surfaces, it is likely that $\mathrm{O}_{2}$ forms via peroxo species on $\mathrm{BiVO}_{4}$, similar to the process that occurs on $\mathrm{TiO}_{2} \cdot{ }^{46,47}$ In the case of $\mathrm{Bi}_{4} \mathrm{~V}_{2} \mathrm{O}_{11}$, because the $\mathrm{VB}$ is composed of hybrid $\mathrm{O} 2 \mathrm{p}$ and $\mathrm{Bi} 6 \mathrm{~s}$ orbitals of the $\left(\mathrm{Bi}_{2} \mathrm{O}_{2}\right)^{2+}$ layers, the intermediate species would be the hydroperoxo group.

Fig. 9 shows the action spectrum for overall pure-water splitting by $\mathrm{ZnRh}_{2} \mathrm{O}_{4} / \mathrm{Ag} / \mathrm{s}-\mathrm{Bi}_{4} \mathrm{~V}_{2} \mathrm{O}_{11}$. We calculated the total number of incident photons from each LED light source and the $\mathrm{O}_{2}$-evolution rates from the slopes of the plots in Fig. 8a-d and then estimated the AQE values (Table S1 in the ESI $6 \dagger$ ). Because the $\mathrm{H}_{2}$ and $\mathrm{O}_{2}$ evolution rates were 2:1 for all wavelengths, the obtained AQE values for $\mathrm{O}_{2}$ evolution were nearly identical to those for $\mathrm{H}_{2}$ evolution. The shape of the action spectrum for overall water splitting by $\mathrm{ZnRh}_{2} \mathrm{O}_{4} / \mathrm{Ag} / \mathrm{s}-\mathrm{Bi}_{4} \mathrm{~V}_{2} \mathrm{O}_{11}$ was more similar to that of the PA spectrum of $s-\mathrm{Bi}_{4} \mathrm{~V}_{2} \mathrm{O}_{11}$ than that of the UV-vis absorption spectrum of $s-\mathrm{Bi}_{4} \mathrm{~V}_{2} \mathrm{O}_{11}$. An identical phenomenon was observed for the action spectrum of $\mathrm{s}-\mathrm{Bi}_{4} \mathrm{~V}_{2} \mathrm{O}_{11}$ for $\mathrm{O}_{2}$ evolution in aqueous $\mathrm{Ce}^{4+}$ solution (Fig. 7), indicating that the overall pure-water splitting reaction proceeded via the band-gap excitation of $\mathrm{s}-\mathrm{Bi}_{4} \mathrm{~V}_{2} \mathrm{O}_{11}$, as well as $\mathrm{ZnRh}_{2} \mathrm{O}_{4}$, which has an $E_{\mathrm{g}}$ value of $1.2 \mathrm{eV}$, and can therefore absorb longer wavelength light than $\mathrm{s}-\mathrm{Bi}_{4} \mathrm{~V}_{2} \mathrm{O}_{11}$. For this reason, the AQE values reflected the active photoabsorption capacity of $\mathrm{s}-\mathrm{Bi}_{4} \mathrm{~V}_{2} \mathrm{O}_{11}$.

To confirm the liberation of $\mathrm{O}_{2}$ from water by $\mathrm{ZnRh}_{2} \mathrm{O}_{4} / \mathrm{Ag} /$ $\mathrm{S}-\mathrm{Bi}_{4} \mathrm{~V}_{2} \mathrm{O}_{11}$, water splitting with water containing $33 \% \mathrm{H}_{2}{ }^{18} \mathrm{O}$ 


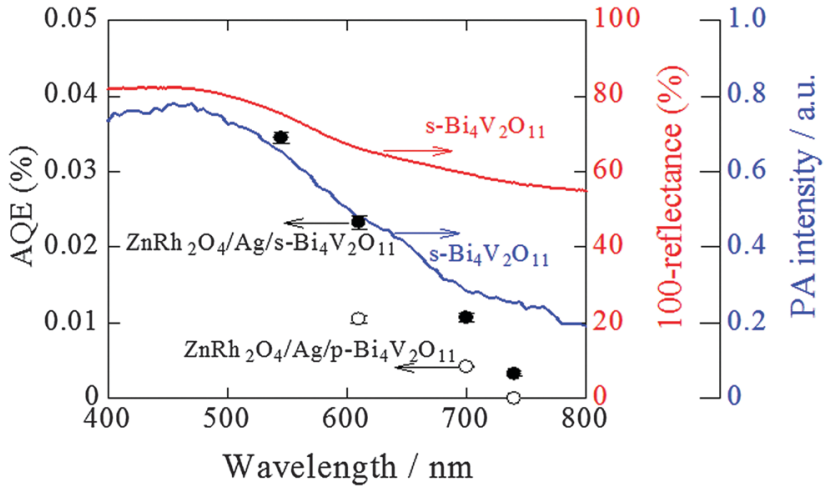

Fig. 9 Action spectra for $\mathrm{O}_{2}$ evolution from pure water by $\mathrm{ZnRh}_{2} \mathrm{O}_{4} / \mathrm{Ag} /$ $\mathrm{s}-\mathrm{Bi}_{4} \mathrm{~V}_{2} \mathrm{O}_{11}$ (solid circles) and $\mathrm{ZnRh}_{2} \mathrm{O}_{4} / \mathrm{Ag} / \mathrm{p}-\mathrm{Bi}_{4} \mathrm{~V}_{2} \mathrm{O}_{11}$ (open circles) under irradiation with LED light sources. Note that the $A Q E$ values for $\mathrm{H}_{2}$ evolution were almost identical to those for $\mathrm{O}_{2}$ evolution, as $\mathrm{H}_{2}$ and $\mathrm{O}_{2}$ evolution at a ratio of $2: 1$ was observed. The UV-visible absorption (red line) and PA (blue line) spectra of $s-\mathrm{Bi}_{4} \mathrm{~V}_{2} \mathrm{O}_{11}$ are also shown. The AQE values of $\mathrm{ZnRh}_{2} \mathrm{O}_{4} / \mathrm{Ag} /$ $\mathrm{p}-\mathrm{Bi}_{4} \mathrm{~V}_{2} \mathrm{O}_{11}$ irradiated with $610 \mathrm{~nm}$ and $700 \mathrm{~nm}$ LED are cited from ref. 27.

under irradiation with $740 \mathrm{~nm}$ light (740 $\mathrm{nm}$ LED, the same intensity in Fig. 8d) was next examined (Fig. 10). The amount of ${ }^{16} \mathrm{O}^{16} \mathrm{O}$ (calc. ${ }^{16} \mathrm{O}^{16} \mathrm{O}$ ) was obtained using the equation calc. ${ }^{16} \mathrm{O}^{16} \mathrm{O}=$ obs. ${ }^{16} \mathrm{O}^{16} \mathrm{O}-$ (obs. $\left.{ }^{14} \mathrm{~N}^{14} \mathrm{~N} / 0.78\right) \times 0.21$, because the detected ${ }^{14} \mathrm{~N}^{14} \mathrm{~N}\left(\mathrm{~N}_{2}\right)$ originated from external air that entered the GC/MS system rather than from air dissolved in water, as was demonstrated in our previous report. ${ }^{26,27}$ Under irradiation with $740 \mathrm{~nm}$ light for $120 \mathrm{~h},{ }^{16} \mathrm{O}^{16} \mathrm{O},{ }^{16} \mathrm{O}^{18} \mathrm{O}$, and ${ }^{18} \mathrm{O}^{18} \mathrm{O}$ were detected at a ratio of $4.00: 3.97: 1.03$, which was close to the theoretical ratio of $4: 4: 1$ for overall water-splitting. In addition, the time course of total $\mathrm{O}_{2}$ evolution $\left({ }^{16} \mathrm{O}^{16} \mathrm{O}+\right.$ ${ }^{16} \mathrm{O}^{18} \mathrm{O}+{ }^{18} \mathrm{O}^{18} \mathrm{O}$ ) using water containing $33 \% \mathrm{H}_{2}{ }^{18} \mathrm{O}$ was consistent with that using normal $\mathrm{H}_{2}{ }^{16} \mathrm{O}$ (solid circles with a solid line in Fig. 10, the same data as in Fig. 8d with the same symbol). Therefore, it was confirmed that $\mathrm{O}_{2}$ was evolved from water by $\mathrm{ZnRh}_{2} \mathrm{O}_{4} / \mathrm{Ag} / \mathrm{s}-\mathrm{Bi}_{4} \mathrm{~V}_{2} \mathrm{O}_{11}$ under irradiation with $740 \mathrm{~nm}$ light. Based on these results, we confidently concluded that $\mathrm{ZnRh}_{2} \mathrm{O}_{4} / \mathrm{Ag} / \mathrm{s}-\mathrm{Bi}_{4} \mathrm{~V}_{2} \mathrm{O}_{11}$ was capable of overall pure-water splitting

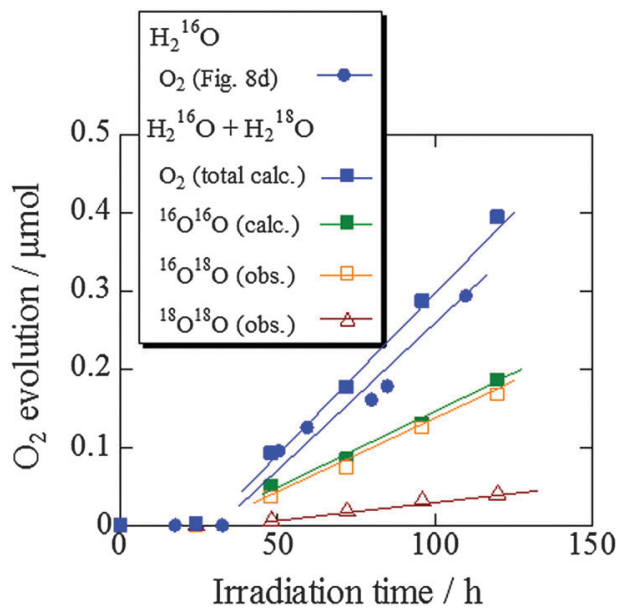

Fig. $10 \mathrm{GC} / \mathrm{MS}$ spectrometry results for the splitting of water containing $33 \% \mathrm{H}_{2}{ }^{18} \mathrm{O}$ by $\mathrm{ZnRh}_{2} \mathrm{O}_{4} / \mathrm{Ag} / \mathrm{s}-\mathrm{Bi}_{4} \mathrm{~V}_{2} \mathrm{O}_{11}$ irradiated with $740 \mathrm{~nm}$ LED light. under visible-light irradiation with a wavelength of $740 \mathrm{~nm}$ (Scheme S1 in the ESI 7†).

In a previous study, ${ }^{27}$ we attempted to scale up the overall pure-water splitting reaction by increasing the amounts of $\mathrm{ZnRh}_{2} \mathrm{O}_{4} /$ $\mathrm{Ag} / \mathrm{p}-\mathrm{Bi}_{4} \mathrm{~V}_{2} \mathrm{O}_{11}$ and pure water by a factor of $10(600 \mathrm{mg}$ of photocatalyst was suspended in $120 \mathrm{~mL}$ pure water). Using this approach, the amounts of evolved $\mathrm{H}_{2}$ and $\mathrm{O}_{2}$ increased $\sim 40$ fold, although the amounts of photocatalyst and water were increased only tenfold. Further improvements in the yields of $\mathrm{H}_{2}$ and $\mathrm{O}_{2}$ evolution may be possible by optimization of the ratio of the photocatalyst and water, modifying the shape and/or volume of the reaction vessel, how the light is irradiated, and other chemical engineering-based modifications.

\section{Conclusions}

We prepared the solid-state heterojunction photocatalyst $\mathrm{ZnRh}_{2} \mathrm{O}_{4} / \mathrm{Ag} / \mathrm{s}-\mathrm{Bi}_{4} \mathrm{~V}_{2} \mathrm{O}_{11}$ and demonstrated that this material simultaneously evolves $\mathrm{H}_{2}$ and $\mathrm{O}_{2}$ from pure water at a molar ratio of $\sim 2$ to 1 under irradiation with nearly the entire range of visible light at wavelengths of up to $740 \mathrm{~nm}$. Through the use of $\mathrm{s}-\mathrm{Bi}_{4} \mathrm{~V}_{2} \mathrm{O}_{11}$ in place of $\mathrm{p}-\mathrm{Bi}_{4} \mathrm{~V}_{2} \mathrm{O}_{11}$, the $\mathrm{AQE}$ for overall water splitting was increased and the sensitivity of the system was increased to wavelengths up to $740 \mathrm{~nm}$. $\mathrm{ZnRh}_{2} \mathrm{O}_{4}$ was used as the $\mathrm{H}_{2}$ photocatalyst in the present system because it has an $E_{\mathrm{g}}$ value of $1.2 \mathrm{eV}$ and is therefore capable of effectively utilizing both visible and infrared light. Despite this desirable property, $\mathrm{ZnRh}_{2} \mathrm{O}_{4}$ is not suitable for large-scale systems because it contains $\mathrm{Rh}$, which is a rare chemical element. Moreover, in this system, $\mathrm{HNO}_{3}$ treatment is required for removing the excess $\mathrm{Ag}$ to achieve overall pure-water splitting, because $\mathrm{Ag}$ acts as a sacrificial agent for $\mathrm{O}_{2}$ evolution. Such treatment might damage $\mathrm{ZnRh}_{2} \mathrm{O}_{4}$ and $\mathrm{Bi}_{4} \mathrm{~V}_{2} \mathrm{O}_{11}$, leading to decreased photocatalytic activity. To avoid such damage and potentially further improve the activity, we replaced $\mathrm{Ag}$ with gold $(\mathrm{Au})$, because $\mathrm{Au}$ is stable and does not act as acrificial agent, and confirmed that an Au-inserted $\mathrm{ZnRh}_{2} \mathrm{O}_{4}$ and $\mathrm{Bi}_{4} \mathrm{~V}_{2} \mathrm{O}_{11}$ $\left(\mathrm{ZnRh}_{2} \mathrm{O}_{4} / \mathrm{Au} / \mathrm{s}^{-} \mathrm{Bi}_{4} \mathrm{~V}_{2} \mathrm{O}_{11}\right)$ system is capable of overall pure-water splitting. Detailed studies of $\mathrm{ZnRh}_{2} \mathrm{O}_{4} / \mathrm{Au} / \mathrm{s}-\mathrm{Bi}_{4} \mathrm{~V}_{2} \mathrm{O}_{11}$ are currently underway in our laboratory.

\section{Acknowledgements}

This study was partially supported by the Cooperative Research Program of Institute for Catalysis, Hokkaido University (Grant \#15A1002). We express gratitude to Prof. Dr Tanaka and Ms Maruyama for their support with the back-reflection Laue pattern measurements. We also thank Mr G. Newton for the careful reading of the manuscript.

\section{Notes and references}

1 A. Fujishima and K. Honda, Nature, 1972, 238, 37-38.

2 J. Sato, N. Saito, H. Nishiyama and Y. Inoue, J. Phys. Chem. $B, 2001,105,6061-6063$. 
3 K. Domen, A. Kudo, T. Onishi, N. Kosugi and H. Kuroda, J. Phys. Chem., 1986, 90, 292-295.

4 H. Kato, K. Asakusa and A. Kudo, J. Am. Chem. Soc., 2003, 125, 3082-3089.

5 K. Domen, J. Kondo, M. Hara and T. Takata, Bull. Chem. Soc. Jpn., 2000, 73, 1307-1331.

6 A. Kudo, Int. J. Hydrogen Energy, 2007, 32, 2673-2678.

7 K. Maeda, R. Abe and K. Domen, J. Phys. Chem. Lett., 2011, 115, 3057-3064.

8 K. Maeda, K. Teramura, D. Lu, T. Takata, N. Saito, Y. Inoue and K. Domen, Nature, 2006, 440, 295.

9 K. Maeda, T. Takata, M. Hara, N. Saito, Y. Inoue, H. Kobayashi and K. Domen, J. Am. Chem. Soc., 2005, 127, 8286-8287.

10 K. Maeda, K. Teramura, T. Takata, M. Hara, N. Saito, K. Toda, Y. Inoue, H. Kobayashi and K. Domen, J. Phys. Chem. B, 2005, 109, 20504-20510.

11 K. Teramura, K. Maeda, T. Saito, T. Takata, N. Saito, Y. Inoue and K. Domen, J. Phys. Chem. B, 2005, 109, 21915-21921.

12 Y. Lee, H. Terashima, Y. Shimodaira, K. Teramura, M. Hara, H. Kobayashi, K. Domen and M. Yashima, J. Phys. Chem. C, 2007, 111, 1042-1048.

13 H. Liu, J. Yuan, W. Shangguan and Y. Teraoka, J. Phys. Chem. C, 2008, 112, 8521-8523.

14 N. Lei, M. Tanabe and H. Irie, Chem. Commun., 2013, 49, 10094-10096.

15 P. Dhanasekaran and N. M. Gupta, Int. J. Hydrogen Energy, 2012, 37, 4897-4907.

16 R. Asai, H. Nemoto, Q. Jia, K. Saito, A. Iwase and A. Kudo, Chem. Commun., 2014, 50, 2543-2546.

17 L. Liao, Q. Zhang, Z. Su, Z. Zhao, Y. Wang, Y. Li, X. Lu, D. Wei, G. Feng and Q. Yu, et al., Nat. Nanotechnol., 2014, 9, 69-73.

18 C. Pan, T. Takata, M. Nakabayashi, T. Matsumoto, N. Shibata, Y. Ikuhara and K. Domen, Angew. Chem., Int. Ed., 2015, 54, 1-6.

19 J. Liu, Y. Liu, N. Liu, Y. Han, X. Zhang, H. Huang, Y. Lifshitz, S. T. Lee, J. Zhong and Z. Kang, Science, 2015, 347, 970-974.

20 K. Sayama, K. Mukasa, R. Abe, Y. Abe and H. Arakawa, J. Photochem. Photobiol., A, 2002, 148, 71-77.

21 H. Kato, Y. Sasaki, A. Iwase and A. Kudo, Bull. Chem. Soc. Jpn., 2007, 80, 2457-2464.

22 A. Kudo, Pure Appl. Chem., 2007, 79, 1917-1927.

23 S. Tanigawa and H. Irie, Appl. Catal., B, 2016, 180, 1-5.

24 Y. Sasaki, H. Nemoto, K. Saito and A. Kudo, J. Phys. Chem. C, 2009, 113, 17536-17542.
25 A. Iwase, Y. H. Ng, Y. Ishiguro, A. Kudo and R. Amal, J. Am. Chem. Soc., 2011, 133, 11054-11057.

26 R. Kobayashi, S. Tanigawa, T. Takashima, B. Ohtani and H. Irie, J. Phys. Chem. C, 2014, 118, 22450-22456.

27 R. Kobayashi, K. Kurihara, T. Takashima, B. Ohtani and H. Irie, J. Mater. Chem. A, 2016, 4, 3061-3067.

28 N. Yasuda, M. Miyayama and T. Kudo, Mater. Res. Bull., 2001, 36, 323-333.

29 N. Murakami, O. O. P. Mahaney, T. Torimoto and B. Ohtani, Chem. Phys. Lett., 2006, 426, 204-208.

30 N. Murakami, O. O. P. Mahaney, R. Abe, T. Torimoto and B. Ohtani, J. Phys. Chem. C, 2007, 111, 11927-11935.

31 G. Mairesse, P. Roussel, R. N. Vannier, M. Anne, C. Pirovano and G. Nowogrocki, Solid State Sci., 2003, 5, 851-859.

32 H. Irie, Y. Watanabe and K. Hashimoto, J. Phys. Chem. B, 2003, 107, 5483-5486.

33 Y. Takimoto, T. Kitta and H. Irie, Int. J. Hydrogen Energy, 2012, 37, 134-138.

34 Y. Lu, Y. Pu, J. Wang, C. Qin, C. Chen and H. J. Seo, Appl. Surf. Sci., 2015, 347, 719-726.

35 V. Thakral and S. Uma, Mater. Res. Bull., 2010, 45, 1250-1254.

36 S. Kumar and P. D. Sahare, NANO: Brief Rep. Rev., 2013, 8, 1350007.

37 X. Chen, J. Liu, H. Wang, Y. Ding, Y. Sun and H. Yan, J. Mater. Chem. A, 2013, 1, 877-883.

38 I. Justicia, P. Ordejon, G. Canto, J. L. Mozos, J. Fraxedas, G. A. Battiston, R. Gerbasi and A. Figueras, Adv. Mater., 2002, 14, 1399-1402.

39 T. Ishii, H. Kato and A. Kudo, J. Photochem. Photobiol., A, 2004, 163, 181-186.

40 R. Konta, T. Ishii, H. Kato and A. Kudo, J. Phys. Chem. B, 2004, 108, 8992-8995.

41 H. W. Kang, S. N. Lim and S. B. Park, Int. J. Hydrogen Energy, 2012, 37, 4026-4035.

42 H. W. Kang and S. B. Park, Mater. Sci. Eng., B, 2016, 211, 67-74.

43 T. Uchihara, M. Matsumura, A. Yamamoto and H. Tsubimura, J. Phys. Chem., 1989, 93, 5870-5874.

44 J. F. Gomes, C. A. Martins, M. J. Giz, G. Tremiliosi-Filho and G. A. Camera, J. Catal., 2013, 301, 154-161.

45 J. Yang, D. Wang, X. Zhou and C. Li, Chem. - Eur. J., 2013, 19, 1320-1326.

46 T. Kisumi, A. Tsujiko, K. Murakoshi and Y. Nakato, J. Electroanal. Chem., 2003, 545, 99-107.

47 R. Nakamura and Y. Nakato, J. Am. Chem. Soc., 2014, 126, 1290-1298. 